ARTICLE

\title{
Revisiting Legal Capital
}

\section{Eilís Ferran ${ }^{1}$}

Published online: 3 September 2019

(c) The Author(s) 2019

\begin{abstract}
This paper argues for the UK to revisit the legal capital (maintenance of capital) doctrine. Leaving the EU could present an opportunity but to reform legal capital just because Brexit may make it possible to do so would have little merit. Three more substantial reasons for revisiting legal capital are developed: the evidence against legal capital being an effective bulwark against short termist corporate behaviour has continued to stack up; difficulties associated with applying legal rules on distributions in the context of modern financial reporting requirements have persisted; and we have a clearer sense of how creditors' interests are affected by moving away from legal capital to solvency standards. The paper locates the need to revisit legal capital within the broader agenda for a system of effective corporate governance and regulation that supports economically worthwhile and sustainable business activity.
\end{abstract}

Keywords Legal capital · Solvency standards · Short termism · Distributions · Financial reporting $\cdot$ Corporate governance

\section{Introduction}

The modernisation of company law in the UK at the start of the twenty-first century settled on an 'enlightened' version of shareholder value as the legal basis for companies to be led in ways that would be both profitable for shareholders and good for society. But years of financial crisis, austerity, rising inequality and environmental degradation have undermined 'win-win', 'doing well by doing good' assumptions and turned the tide in favour of more radical prescriptions for the reconceptualisation of the corporation. Whilst this movement has not yet resulted in extensive legal reform, the unstable and unpredictable state of British politics makes it plausible to envisage that bold new ideas could gain traction.

This paper actually focuses on an old idea-reform of the legal capital (maintenance of capital) doctrine-but the topic has more political salience than might

Eilís Ferran

evf1000@cam.ac.uk

1 Professor of Company and Securities Law, University of Cambridge, Cambridge, UK 
initially be associated with such a technically complex field. There are legal capital issues at the intersection of some of the main current controversies in company law and corporate governance - the respective roles of management and investors in delivering sustainable, long-term business success for the benefit of society as a whole, the quality of the accounting and audit services provided to the corporate sector, and the robustness of oversight and enforcement mechanisms for both directors' duties and the provision of accounting and audit services. Legal capital is also an apt topic for a volume to mark the 20th anniversary of the Centros decision, which was a powerful catalyst for the dynamic dismantling of minimum capital requirements in national company laws.

Brexit makes it timely to revisit the legal capital debate. The UK's influence on EU company law as an EU Member State was recently examined in a thoughtful article by Martin Gelter and Alexandra Reif. ${ }^{1}$ For Gelter and Reif, the way in which the UK was most able to use its membership position was by acting as a 'brake' on the first wave of EU harmonisation relating to core company law areas such as board structure and legal capital. Although the development of EU takeover, accounting and corporate governance geared to the needs of the capital markets during the 1990s and 2000s was broadly consistent with British preferences, the authors suggest that this was less to do with active pressure from the UK within EU legislative processes than with its high reputation as a model jurisdiction for the design of corporate governance and capital markets regulation. In this sense, the UK's membership of the EU could be described as irrelevant for harmonisation in areas relating to capital markets because the real driver was market forces.

So far as Brexit is concerned, this chapter turns the inquiry in the opposite direction: the EU's influence on UK company law where EU membership acted as a brake on the design of substantive domestic laws. This question has not yet received close attention. To be clear, some scholars have begun to explore possible effects of Brexit on the future trajectory of company law in the UK but this inquiry has focused primarily on cross-border mobility on the basis of freedom of establishment, and cross-border restructuring and reorganisation. ${ }^{2}$ Freedom of establishment is a particular concern in the Brexit context because the Court of Justice caselaw that protects companies that incorporate in one Member State but have their real seat in another will not apply to UK companies if the UK becomes a third country and that could mean that a UK corporate vehicle is no longer recognised as such in Member States' national conflict of laws or in international law treaties, which could then result in shareholders being exposed to personal liability. ${ }^{3}$ The existing literature does not examine in detail areas where EU membership has been seen to constrain the development of UK company law, presumably because those areas do not present as top priority candidates for immediate post-Brexit significant reform.

\footnotetext{
1 Gelter and Reif (2017).

2 Armour et al. (2017); Schillig (2016); Böckli et al. (2017).

3 European Commission, 'Notice to Stakeholders: Withdrawal of the United Kingdom and EU Rules on Company Law’, 21 November 2017.
} 
However, as the UK adjusts over time to its third country status, these areas may come to the foreground. Legal capital is one such area.

Section 2 outlines how and why modernisation of legal capital in UK company law was held back by obligations arising from EU membership. Section 3 locates the need for reform of legal capital within the broader agenda for a system of effective corporate governance and regulation that supports economically worthwhile and sustainable business activity. Section 4 then examines in more detail the case for moving away from legal capital and Sect. 5 considers what we have learnt from taking a significant step in that direction in the reduction of capital context. Section 6 looks at dividends, which in many ways is the most contentious area because the historic concern that legal capital unjustifiably restricted dividend-paying capacity has been replaced by a broader concern that dividend payments are excessive and benefit shareholders at the expense of long-term corporate sustainability. Section 7 briefly concludes.

\section{EU Law as a Brake on Domestic Company Law in the UK: Legal Capital}

The baleful influence of the EU on the design of domestic company law in the UK is strongly associated with the legal capital doctrine, which takes effect by way of a suite of rules relating to the raising and maintenance of share capital. The Second Company Law Directive (1976) (now codified as part of Directive (EU) 2017/11324 but for convenience still referenced here by its historic name) harmonised at a minimum level legal capital requirements for public companies for the protection of creditors and shareholders. The Advocate General of the European Court of Justice has pinpointed 'the essential purpose' of the Directive as being 'to maintain the balance of powers between the different organs of the company, especially in case of conflicts between those organs'. ${ }^{5}$ The Directive was lightly amended in $2006^{6}$ but against a background of mounting criticism that its approach had not kept pace with developments in corporate finance, capital markets and financial reporting, the failure to do more to update the Directive was regarded by many as a missed opportunity.

A re-examination of the extensive reviews that preceded the Companies Act 2006, the last comprehensive overhaul of company law in the UK, shows that at that time the need to remain consistent with EU rules was seen to be a barrier to

\footnotetext{
${ }^{4}$ Directive (EU) 2017/1132 of the European Parliament and of the Council of 14 June 2017 relating to certain aspects of company law [2017] OJ L169/46.

5 Case C-526/14 Kotnik and others v. Državni zbor Republike Slovenije, ECLI:EU:C:2016:570, [2017] 1 CMLR 753. This case and also Case C-41/15 Dowling v. Minister for Finance, ECLI:EU:C:2016:836, [2017] 3 CMLR 27, establish that these protections relate to normal times and that they give way in the face of exceptional measures taken by national authorities in response to serious disturbance of the economy and which are aimed at ensuring EU systemic safety and stability.

${ }^{6}$ Directive 2006/68/EC [2006] OJ L264/32.
} 
desirable reform. ${ }^{7}$ In a White Paper that preceded the new Act, the government explained that 'In advance of significant amendments to the EU legislation, it would not be possible to make major changes to our capital maintenance regime in respect of public companies' and that it would therefore give priority to 'fundamental reform of the capital maintenance regime through reform of the 2nd Company Law Directive'. ${ }^{8}$ This was echoed in Parliament by the government spokesperson: 'On capital maintenance, for example, which is a large chunk of what remains in the 1985 Act, we are pressing for fundamental reform in the EU. To restate in advance of that would not be helpful for users'. ${ }^{9}$ The UK government's desire for meaningful reform of the rules on legal capital at the EU level was also seen in its decision to opt only selectively into certain minor changes in the area of legal capital made by the 2006 amending Directive because it was not convinced that the changes not adopted would result in simplification and it was concerned that they would increase the burden of legislation in an already complex area. ${ }^{10}$ The government preferred instead to wait for the outcome of a feasibility study on alternatives to the capital maintenance regime that the European Commission had commissioned ${ }^{11}$ (but which in the end did not amount to much).

\section{Post Brexit Options: The Big Picture}

The constraints arising from EU membership will eventually disappear unless the deal on the future UK-EU relationship obliges the UK to continue to follow the EU rules in this area. ${ }^{12}$ The UK could, if it wished, choose to align its legal capital regime for public companies more closely with the regime for private companies. It could also revisit aspects of the private company regime that were not included in the simplification exercise effected by the Companies Act 2006. The Companies Act 2006 made a number of important changes to the legal capital regime for private companies but stopped short of fully making use of its freedom as a Member State to simplify private company requirements. Specifically, the option of a liquidity/solvency-based approach to private company distributions was not pursued. This was partially justified by reference to the constraining effect of EU membership- the argument being that having different regimes for public and private companies could give rise to intra-group complications-but other factors were also in play, including some lack of conviction as to adequacy of the protection afforded by liquidity/ solvency standards and concern that they could feed short-termism through a failure

\footnotetext{
7 Company Law Review Steering Group (1999a), ch. 3; Company Law Review Steering Group (1999b), ch. 3; Company Law Review Steering Group (2000).

8 Department of Trade and Industry (2005), p 43.

9 Hansard (2006), col. 182, Lord Sainsbury.

10 Department of Trade and Industry (2007), ch. 6.

11 KPMG (2006).

12 As it could—see, e.g., EU-Ukraine Association Agreement, Art. 387 (obliging parties to cooperate on the protection of shareholders, creditors and other stakeholders 'in line with EU rules in this area'.
} 
to give due weight to long-term liabilities. Opting to wait for the EU to move first effectively side-stepped the need to get to the bottom of those concerns.

Post Brexit (assuming a version that leaves the UK free to redesign its company law), it would not be simply a matter of picking up from where things were left in 2006 and completing unfinished business since much has happened in the intervening years. The big picture back then was one where the UK economy was riding high, its capital markets were booming, and its so-called 'light touch' approach to corporate and financial regulation was seen to be a powerful magnet for international businesses. 'Deregulation' was a buzzword of the period. Today, the talk is more of the social contract between companies and wider society having broken down. ${ }^{13}$ Short-termism on the part of corporate managers and/or institutional investors is a major public policy concern and there is evidence that the problems are getting worse rather than better. ${ }^{14}$ These problems are strongly associated with decisions that companies make about their capital structures and excess liquidity. There is criticism of high payouts through dividends and share buy backs as value-destructive policies that reduce internal funds available for investment; Andy Haldane, chief economist of the Bank of England, has noted that the 'macro-economic consequences of this behaviour are likely to be far from benign'. ${ }^{15}$ According to one study, between 2000 and 2015 total payouts by way of dividends and share buy backs of the UK companies came very close to their total net income during that period. ${ }^{16}$ There are concerns that companies may be repurchasing shares to artificially inflate executive pay, although research commissioned by the government does not support such claims. ${ }^{17}$ There is particular concern also about correlations between high payout levels and deficits on company employee defined benefit pension schemes. ${ }^{18}$ At the extreme, the financial crisis of 2008 revealed the risk-shifting effects of excessive pursuit of short-term profitability for the benefit of shareholders, with creditors and the general public, rather than shareholders, being left to pick up the bill for failure. ${ }^{19}$

If the legal capital doctrine were an effective bulwark against short termist corporate behaviour, it would be hard to make a credible case for reform in the current environment. However, it is not. The longstanding criticism of legal capital is that its approach is not impactful, either for the internal corporate constituencies whose interests it is meant to protect or with respect to broader societal concerns. The doctrine takes effect by way of complicated technical rules that can catch out even listed companies that might have been expected to have access to the professional advice needed to navigate complex rules. As well as being a trap for the unwary, they are also not very effective in addressing real issues - the worst of both worlds, in effect.

\footnotetext{
13 Plender (2018).

14 House of Commons Business, Energy and Industrial Strategy Committee (2017), paras. 19-20.

15 Haldane (2015).

16 Sakinç (2017).

17 Department for Business, Energy and Industrial Strategy (2018a, 2019b).

18 The Pensions Regulator (2018), p 11.

19 Tooze (2018).
} 
That plethora of complicated rules did not for example, prevent, the collapse of British Home Stores (BHS) in 2016 where the payment of substantial dividends in good years was widely understood to have contributed to its subsequent demise. ${ }^{20}$ 'Excessive' dividends relative to pension scheme deficit contributions was also a salient issue in the collapse of Carillion in $2017 .{ }^{21}$ Rules that miss the point, that can be evaded by clever engineering, that force companies into roundabout procedures to forgive 'technical infringements', or that favour one set of interests at the expense of another are potentially worse than useless in that they risk giving a misleading impression and/or impose unnecessary costs.

There is continuing debate in the UK on the checks and balances on strategic corporate decisions, including those relating to capital, investment and returning value to shareholders, that will best support long term success. One of the key policy choices reflected in the Companies Act 2006 was to retain a shareholder focus for directors' duties rather than a 'pluralist' approach that would have required them to consider the interests of shareholders alongside those of employees, creditors and other stakeholders. The 2006 Act famously sought in section 172 to put an 'enlightened' gloss on the shareholder focus by requiring directors to 'have regard' to other stakeholders and the likely long term consequences of their decisions. Whether section 172 has succeeded in effecting substantive change to the way that companies are run remains open to question. ${ }^{22}$ At best it may have some 'deterrent' effect. ${ }^{23}$ More ambitious options such as mandatory worker representation on corporate boards to ensure that critical decisions reflect a range of views come to prominence periodically but so far these have struggled to gain serious traction. ${ }^{24}$ Recent changes have moved only rather modestly in a more pluralist direction, for example: new provisions in the non-binding Corporate Governance Code asking the boards of listed companies to describe how they have considered the interests of stakeholders when performing their duty under section 172 of the 2006 Companies Act and to improve engagement with the workforce, with the option of appointing a director from the workforce specified as one of the methods by which this could be achieved; ${ }^{25}$ new non-binding Corporate Governance Principles for large private companies that expect meaningful engagement and good relationships with material stakeholders

\footnotetext{
20 Safari and Gelter (2019).

21 House of Commons Business, Energy and Industrial Strategy and Work and Pensions Committees (2018).

22 There is a vast academic literature but the following selection gives a flavour of the scepticism that has dogged section 172: Keay (2012); Williams (2012); Lynch (2012); Grier (2014).

23 House of Commons Business, Energy and Industrial Strategy and Work and Pensions Committees (2018), para. 166 (noting that any deterrent effects provided by section 172 had been insufficient in that case).

24 This was seen in 2016/7 when the government floated a range of options for strengthening the consideration of the interests of employees, customers and wider stakeholders in corporate decision making including the possibility of worker representation on boards: Department for Business, Energy and Industrial Strategy (2017), sect. 2.

25 The revised Financial Reporting Council (FRC) Corporate Governance Code was published in July 2018.
} 
including the workforce; ${ }^{26}$ and new strategic report disclosure obligations related to section $172 .^{27}$

Should the predictions of a serious breakdown in businesses' social contract that have followed in the wake of BHS and Carillion prove correct, it is possible that this could stimulate further serious discussion of pro-worker corporate governance policies. ${ }^{28}$ Historically, the debate on the fundamental orientation of directors' duties has proceeded largely without reference to the seemingly arcane technicalities of the rules arising from the legal capital doctrine, even though those rules establish baseline conditions that frame the space within which strategic corporate decisions about investment in corporate development, projects and workforce/returning value to shareholders come to be made. However, this is beginning to change: BHS and Carillion have put aspects of legal capital on the Conservative government radar. ${ }^{29}$ Although there is no sign of an appetite for significant change in the short term, the government has undertaken to review the strength of the case for a comprehensive review of the UK's dividend regime and has indicated a willingness to legislate or take other steps in the event that market-based solutions do not resolve transparency-related concerns. ${ }^{30}$ Recent proposals from the opposition Labour party have included tightening the rules on legal capital, including reversing changes made by the Companies Act 2006, as part of a package to reform company law in a more communitarian direction. ${ }^{31}$

The view advocated here is that placing faith in rules that have become internationally discredited and that can get in the way of economically worthwhile activity would be a wrong turn. Whilst corporate scandals such as BHS and Carillion certainly indicate that there are deficiencies in the existing framework within which judgments on payouts to shareholders come to be made, correcting those deficiencies should be seen, therefore, to be an exercise that extends far beyond the technicalities of legal capital. It is right to ask, as the government has done, whether the framework within which companies determine dividend payments is fit for purpose and the decision to look again at the case for comprehensive reform is welcome. ${ }^{32}$ However, getting the whole system right involves thinking about an array of issues including: the reliability of corporate accounts; ${ }^{33}$ the inevitable dependency of directors on specialist advice from accountants in such a complex area and how that

\footnotetext{
${ }^{26}$ FRC, Wates Corporate Governance Principles for Large Private Companies, December 2018.

27 The Companies (Miscellaneous Reporting) Regulations 2018, amending Companies Act 2006.

28 Moore (2017).

29 Department for Business, Energy and Industrial Strategy (2018b), pp 28-29.

30 Department for Business, Energy and Industrial Strategy (2018b, 2018c), paras. 1.46-1.55.

31 Hudson (2016); Hudson (2018).

32 Department for Business, Energy and Industrial Strategy (2018c).

33 Brexit presents an opportunity to consider whether to continue to adopt International Financial Reporting Standards (IFRS) for reporting by listed companies. A strong case has been made for the UK to retain the IFRS reporting framework: ICAEW Financial Reporting Faculty (2017). But it has been argued that Brexit could provide a valuable opportunity to review other aspects of the annual company reporting framework and the interface between legal requirements and accounting standards: WalkerArnott (2017).
} 
affects the ability of the directors to discharge their personal non-delegable duties; ${ }^{34}$ the robustness of the challenge provided by auditors ${ }^{35}$ the effectiveness of oversight arrangements relating to financial reporting and auditors, ${ }^{36}$ and of mechanisms of enforcement of directors' and auditors' duties more generally; ${ }^{37}$ and whether there is a need to reinforce powers to reverse value-extraction actions taken close to insolvency $^{38}$ and/or to reinforce regulatory intervention powers to ensure pensions are protected. ${ }^{39}$ Care is needed to ensure that the array ${ }^{40}$ of changes and consultations on proposed reforms on many of these issues is properly coordinated. Whilst narrower questions relating to the legal capital doctrine as such are the focus of the rest of this article it is important to stress that they should be viewed as an integral part of a much larger agenda.

\section{Why Move Away from Legal Capital? A Deeper Dive into the Case for Reform}

In simple terms the legal capital doctrine is about ex ante protection for different constituencies within a company.

The legal capital doctrine is primarily associated with creditor protection and seeks to protect creditors by saying that only that portion of the net assets that exceeds the capital and undistributable reserves can be paid out to shareholders. Critics argue that the protection of the extra layer constituted by capital and undistributable reserves is insignificant or potentially even illusory because it is not riskweighted, that the legal capital doctrine fundamentally misses the point because

\footnotetext{
${ }^{34}$ Department for Business, Energy and Industrial Strategy (2018b), pp 30-31 raised the question whether directors understand that the commissioning of professional advice (e.g. on the amount of available distributable profits) does not relieve them of the responsibility to exercise independent judgment. But Department for Business, Energy and Industrial Strategy (2018c), paras. 1.56-1.67 does not highlight this as a major problem. There are also more technical questions about the extent to which reliance on expert advice insulates directors from liability for signing off on defective accounts: Walker-Arnott (2017).

35 During 2018, the FRC (itself under attack-see the following note) became increasingly vocal in calling upon the audit profession to improve the standard of its services, e.g.: FRC (2018a, b).

36 A string of corporate scandals (BHS, Carillion) and audit failures led to stinging criticism of the FRC: e.g. House of Commons Business, Energy and Industrial Strategy and Work and Pensions Committees (2018). This, in turn, prompted an independent review led by Sir John Kingman, which concluded that that the FRC should be abolished and replaced with an independent statutory regulator called the Audit, Reporting and Governance Authority: Kingman (2018). The Kingman recommendations are being taken forward: Department for Business, Energy and Industrial Strategy (2019a).

37 Safari and Gelter (2019).

38 Department for Business, Energy and Industrial Strategy (2018b), pp 13-18 suggested the introduction of new powers going beyond those in existing insolvency legislation for insolvency office-holders to challenge value extraction schemes. However, Department for Business, Energy and Industrial Strategy (2018c), section 3 is more focused on improvements to existing recovery powers than on the introduction of new powers and there is considerable stress on the need for 'balance' so as not to deter investment in the market for turnaround finance.

39 Department for Work and Pensions (2018).

${ }^{40}$ Immediately previous notes refer.
} 
what creditors really care about is ability to meet short-term obligations (i.e. liquidity) and longer-term financial commitments (i.e. solvency), and that costly, timeconsuming procedures to comply with detailed legal capital requirements or work around them get in the way of economically worthwhile transactions. ${ }^{41}$ One particular source of complexity in the UK (where national law actually gold plates EU requirements $)^{42}$ is that distributable reserves are formed by realised profits. Modern trends in accounting have exacerbated conceptual differences between accounting profits and realised profits and have increased volatility around what counts as a realised profit. These trends have given extra impetus to the critics who question whether the extra comfort that creditors gain from there being a layer of reserves that are deemed to be undistributable outweighs the rigidities and complexities associated with the legal capital approach.

The legal capital doctrine protects shareholders principally by mandating shareholder approval by ordinary or special (super-majority) resolution of certain corporate actions relating to capital. Specific shareholder empowerment is an important element of modern corporate governance and is intended to address agency concerns between management and shareholders. So far as shareholder interests are concerned, the debate on the legal capital doctrine is thus less about sweeping away fundamentally outdated requirements than about identifying the shareholder approval requirements that it would be appropriate to retain in a modernised regime relating to corporate actions on capital, recognising that the process of obtaining shareholder approval usually results in additional costs and delay.

The legal capital doctrine does not directly protect employees, pension funds or other stakeholders as such (though employees etc. may also be creditors) or have societal benefit as its direct purpose, and these broader interests are addressed only to the extent that they align with creditor and shareholder interests. From stakeholder and societal perspectives there is a major downside to shareholder empowerment strategies because short-termism on the part of equity investors means that shareholders cannot be relied upon always to do the right thing for other constituencies within the company or for society at large. There is increasing scepticism that initiatives that seek to foster better stewardship by institutional investors to support sustainable long-term success do enough to address these wider concerns. ${ }^{43}$

No one doubts that company law should protect creditors and shareholders but much of the world, including leading jurisdictions in the common law world that constitutes the UK's historic legal family, has decided that the prescriptive rules that

\footnotetext{
41 For an overview of the competing arguments and references to the academic literature see Ferran and Ho (2013).

42 KPMG (2006), p 129, noting the distinction between realised and accounting profit as a 'particularity' of the UK system.

43 The Stewardship Code was described to be ineffective by the parliamentary committee that investigated Carillion: House of Commons Business, Energy and Industrial Strategy and Work and Pensions Committees (2018), para. 179. The Kingman Review of the FRC was equally scathing: Kingman (2018). In January 2019 the FRC launched a consultation on a new Stewardship Code that, it claimed, would set substantially higher expectations for investor stewardship policy and practice with a view to delivering sustainable value for beneficiaries, the economy and society. However, the Kingman Review has held out a threat of abolition of the Code if it cannot evolve beyond being a driver of boilerplate reporting.
} 
flow from the legal capital doctrine are not the best way to do so. The Companies Act 2006 was a partial step in the 'modern', more flexible direction. As we contemplate the prospects for further reform in a post Brexit era it is worthwhile to consider how changes introduced by that Act have fared and what we have learnt from them: have businesses valued the greater flexibility and made use of it; and to the extent that practice has changed, have there been any signs that this has come at too great a cost in terms of creditor or shareholder (and indirectly, other constituencies') protection? The next section explores.

\section{What Have We Learnt from Modernisation So Far? A Solvency-Based Approach to Reduction of Capital}

So far as creditors' interests are concerned, the Companies Act 2006 made an important move away from the legal capital approach in the area of reduction of capital by private companies. Whilst the UK companies legislation already made some use of a solvency standards-based approach, the 2006 Act made a significant advance by relaxing the requirement for court involvement in reductions of capital and introducing a new procedure to allow private companies to reduce their capital on the basis of shareholder resolutions and a directors' statement of solvency. Whilst this change also had ramifications for shareholders (because the court-based procedure involves consideration of their interests before a reduction of capital is approved $)^{44}$ it had far more significance for creditors because they lost rights to be informed about, and to object to, proposed reductions, whereas shareholders retained approval rights.

An early report on the practical impact of the solvency statement alternative for the reduction of capital for private companies indicated a degree of caution in taking advantage of the new method. ${ }^{45}$ Only a quarter of eight companies surveyed had used the simplified procedure, although those that had said that it was easier than the court-based route. There were suggestions that companies would opt to continue to go down the court-based route because it was preferable in terms of public trust and delivered a degree of security that outweighed costs savings. ${ }^{46}$ However, more recent indications are that the simplified procedure has grown in popularity and that it is regarded as a more cost-effective procedure. ${ }^{47}$

Has creditor protection been weakened by the introduction of the solvency statement procedure? In this procedure creditors' interests depend on the judgment of the directors who make the solvency statement based on an assessment of the company's ability to pay its debts at the date of the statement and as they fall due during the year immediately following that date. ${ }^{48}$ There is no requirement for the statement to be audited. Creditors are thus exposed to the quality of decision-making by

\footnotetext{
44 Scottish Insurance Corp v. Williams \& Clyde Coal Co Ltd [1949] AC 462, HL.

45 Infogroup/ORC International (2010), pp 117-119.

46 Infogroup/ORC International (2010).

47 Weightmans (2017).

48 Companies Act 2006, s. 643.
} 
directors and in a technical respect it appears that this does put them at a disadvantage compared to the court procedure. This disadvantage arises from the position with respect to liabilities for defects in the operation of the solvency-based procedure. The Companies Act 2006 provides for criminal liability on the part of defaulting directors if they make a solvency statement without having reasonable grounds for the opinions expressed in it and the statement is delivered to the registrar. ${ }^{49}$ The Act is however silent on civil liability consequences. These consequences were in issue in BAT Industries Plc v. Sequana where it was held at first instance that lack of reasonable grounds for the opinions expressed did not render the solvency statement invalid. ${ }^{50}$ In coming to this conclusion, the High Court stressed the importance of certainty and the dangers of retrospectively unravelling declarations of solvency. The argument that this weakened the protection afforded to creditors compared to the statutory procedure did not find favour. The Court rejected the argument there was no reason why creditors should be in any different position when the company used the solvency statement route from the position they would have been in had court approval been sought. The Court considered that Parliament had chosen not to include a mechanism for creditors to be notified of a proposed reduction or to have the right to object and that policy considerations did not require the Court to construe the statutory provisions in any way that was out of the ordinary.

The reasoning in Sequana on this point requires a qualitative and potentially quite fine distinction to be drawn between not conducting the holistic and realistic assessment $^{51}$ needed to come to the required opinions honestly, and not having reasonable grounds for the opinions that were formed. ${ }^{52}$ However, the first instance decision on this point was not appealed. There could be circumstances in which in remedial terms much could turn on the distinction between not conducting the assessment properly and not having reasonable grounds for the opinions formed through that assessment. ${ }^{53}$ In the former situation, the solvency statement would not be properly made, and the civil liability consequences would be those arising from an unlawful reduction of capital/distribution. The orthodox position is that directors who authorise an unlawful distribution face harsh consequences 'however technical the error and however well-meaning the directors who paid it' $;{ }^{\prime}$ and recipient shareholder can be held liable to repay the amounts received. ${ }^{55}$ In the latter situation, however,

\footnotetext{
${ }^{49}$ Companies Act 2006, s. 643(4).

50 Sequana.

51 Trew [2018] EWHC 600 (Ch), para. 182.

52 Trew [2018] EWHC 600 (Ch), para. 182.

53 Trew, paras. 193-197.

54 Toone v. Robbins [2018] EWHC 569 (Ch), para. 48, applying Progress Property Co Ltd v. Moore [2011] 1 WLR 1.

55 Remedies that lie against a shareholder who receives an unlawful distribution are a claim in equity for unconscionable receipt and the statutory remedy under Companies Act 2006, s. 847 (where, as in Sequana, the reduction of capital is used to create a reserve that is later used to pay a dividend). There may also be a claim against shareholders for unjust enrichment. The Insolvency Act 2006 provides other possibilities for setting aside a disputed distribution: s. 238 transaction at an undervalue; s. 239 (preference); s. 423 (transaction defrauding creditors). The Insolvency Act powers can extend to lawful distributions: Sequana.
} 
there would be no unlawful reduction of capital and civil liability consequences would depend on establishing that directors have breached their duty of care and skill and/or their general fiduciary duties with respect to stewardship of the company's assets. ${ }^{56}$

Yet if we step back from the details and return to the broader question whether the relaxation of the law has really put creditors in a worse position it is hard to read such a conclusion into the potential technical differences in remedial consequences revealed by Sequana. After all, the actual decision in Sequana, which was upheld on appeal, was in favour of partial recovery of value extracted from the company by means of dividends funded by distributable reserves created by the disputed reduction of capital. ${ }^{57}$ This was based on an alternative claim that one of the dividends in question constituted a transaction at an undervalue for the purposes of section 423 of the Insolvency Act 1986. This outcome helpfully illustrates the point about the importance of looking at the system as a whole and not decoupling a specific rule from the broader context in which it operates. Further, to the extent that differences in remedial consequences are troubling, the problem could be corrected fairly easily by an appropriately targeted legislative intervention. On this point hindsight seems to confirm that it was a mistake not to adopt reform recommendations in the lead up to the Companies Act 2006 to codify the civil liability consequences where directors are at fault (deliberately or otherwise) in making a solvency statement.

It would be troubling if the solvency statement procedure allowed directors to apply laxer substantive standards than those that would be applied by a court. However, there is not such a glaring difference between the standards applicable to the solvency statement and court-based procedures as to clearly put creditors in a materially worse position in that respect. In the solvency statement procedure directors must base their opinions on an assessment of assets and liabilities (including contingent and prospective liabilities) that is conducted on a holistic and realistic basis. ${ }^{58}$ Case law has established that this does not require directors to assess contingent and prospective liabilities on a worst case scenario $^{59}$ (i.e. 'if calamity were to strike on some or all fronts'). ${ }^{60}$ It has been held that taking account of such liabilities does not mean simply adding them at face value to present liabilities but instead requires the directors to make a judgment based on all the circumstances, including considering practical provisions that the company may be putting in place, such as setting aside specific assets, to meet the liabilities. ${ }^{61}$ Although the solvency test for the purposes of the Companies Act reduction of capital procedure is not the same as the tests for insolvency in the 1986 Act there is some common ground. The reduction of capital case law has therefore drawn upon the leading case on the statutory test of

\footnotetext{
56 Trew, paras. 193-197.

57 [2019] EWCA Civ 112.

58 Companies Act 2006, s. 643; BAT Industries Plc v. Sequana [2016] EWHC 1686 (Ch); LRH Services Ltd v. Trew [2018] EWHC 600 (Ch).

59 Sequana.

60 Sequana, para. 327.

61 Sequana.
} 
insolvency in the Insolvency Act $1986,{ }^{62}$ in which the Supreme Court made it clear that a 'balance sheet' test of insolvency is not rigidly tied to the numbers shown on a company's statutory balance sheet ${ }^{63}$ and is a matter of judgment that should be approached with caution given future unknowns, ${ }^{64}$ that account should be taken of practical arrangements such as insurance to cover liabilities, ${ }^{65}$ and also that any attempt to apply a cash flow/liquidity test beyond the reasonably near future will become completely speculative. ${ }^{66}$

In the court-based procedure for reduction of capital the standards applied by the court are seen through the mechanism whereby creditors have standing to object to a reduction. Since $2009^{67}$ standing is conditional on the creditor being able to show a 'real likelihood' that the reduction would result in the company being unable to discharge their debt when it fell due. ${ }^{68}$ It has been held that the assessment must be grounded on the facts as they are known and must not be speculative and must look forward only for a period in relation to which it is sensible to make predictions. ${ }^{69}$ Working capital models of up to 3 years have been accepted as a sufficient forward look. ${ }^{70}$ The burden of proof is on the creditor to show a causal link between the reduction of capital and the company's inability to discharge their debt. ${ }^{71}$ As well as insurance, the company may resort to other practical arrangements to reassure the court. For example, the company may resist any suggestion that there is any real likelihood of a reduction resulting in inability to discharge liabilities as they fall due by giving an undertaking to retain a portfolio of assets with an appropriate safety margin (a 'locked box') to be used to meet such creditors' claims as they fall due. ${ }^{72}$

Where does this leave us in terms of overall creditor protection? It is a truism to say that 'it is fundamental part of our company law that that capital must be maintained and must not be returned to shareholders except in strictly controlled circumstances', ${ }^{73}$ yet detailed examination of both the court-based and the solvency-based procedures for reduction of capital reveals no inclination nowadays to treat this protection as so 'cast iron' as to require the key assessments to be made by reference to worst case scenarios that stretch far into the future. This position is consistent with the direction of UK company law with respect to creditors more generally.

\footnotetext{
62 BNY Corporate Trustee Services Ltd v. Eurosail [2013] UKSC 28.

63 At para. 1 per Lord Walker.

64 At para. 42 per Lord Walker.

65 At para. 38 per Lord Walker.

66 At para. 37 per Lord Walker.

67 Introduced by the Companies (Share Capital and Acquisition by Company of its Own Shares) Regulations 2009 No. 2022. This change, restricting the category of creditor entitled to object, implemented one of the amendments to the Second Company Law Directive by Directive 2006/68/EC.

68 Companies Act 2006, s. 646(2).

69 Re Liberty International plc [2010] EWHC 1060 (Ch), [2010] 2 BCLC 665; Re Royal Scottish Assurance plc [2011] CSOH 2, 2011 SLT 264; Re Sportech plc [2012] CSOH 58, 2012 SLT 895; Re Vodafone plc [2014] EWHC 1357 (Ch).

70 Re Vodafone.

71 Re Liberty International at para. 11; Re Royal Scottish Assurance at para. 12.

72 E.g., Re Old Mutual plc [2018] EWHC 873 (Ch).

73 Re Northern Engineering Industries plc [1994] B.C.C. 618, CA, at 626 per Millett LJ.
} 
As a general rule in modern UK company law, subject to the section 172 gloss of 'enlightenment', directors are expected to focus on the success of the company for the benefit of members. ${ }^{74}$ This is subject to any rule of law requiring directors to consider or act in the interests of creditors ${ }^{75}$ but on the basis of lengthy analysis of the authorities, the Court of Appeal in Sequana held that the duty becoming creditor-facing only when the directors knew or should have known that the company was or was likely (i.e. probable) to become insolvent; it does not arise simply where there is a long-term liability on the balance sheet and a risk that the liability might later turn out to be larger than the provision that has been made for it. ${ }^{76}$ At the level of the Corporate Governance Code and Listing Rules, as part of their responsibilities in the area of audit, risk and internal control the board should state in the annual report whether it considers it appropriate to adopt the going concern basis of accounting and identify any material uncertainties to the company's ability to continue to do so over a period of at least 12 months from the date of approval of the accounts; it should also assess the company's prospects over a longer period and state whether it has a reasonable expectation that the company will be able to continue in operation and meet its liabilities as they fall due over the period of the assessment. ${ }^{77}$ The second of these provisions relating to longer term viability was introduced into the Code in 2014 and practice continues to evolve but there are indications that many companies are settling on 3 years as the appropriate period for the forward look. ${ }^{78}$

Lagging behind now is the position with respect to distributions to shareholders by way of dividend. This was not included in the legal capital modernisation agenda of the Companies Act 2006 in part for fear that allowing companies to pay dividends on the basis of a solvency statement would result in insufficient provision being made for long term liabilities such as pensions. ${ }^{79}$ Given what we have learnt about the treatment of long-term liabilities in the reduction of capital context-that assessments are based on known facts and forward looking only to the extent that it is possible to do so without dipping into speculation, and that the treatment of future liabilities is a matter of business judgment based on practical considerations, amounting, in effect, to a rather commercial test of future viability - that nervousness might not seem misplaced. Whilst for certain purposes reductions of capital and dividends (and also share buy backs) can be regarded as functionally equivalent mechanisms for returning value to shareholders, an important difference is that there are strong commercial expectations about the stickiness of dividend payments whereas returns of capital are generally regarded as more exceptional, oneoff events. It might be argued, therefore, that the expected regularity of dividend payments magnifies the risk that they will be used as a vehicle for value destruction, and therefore that what works for reduction of capital is not necessarily appropriate

\footnotetext{
74 Companies Act 2006, s. 172.

75 Companies Act 2006, s. 172(3).

76 Sequana.

77 FRC Corporate Governance Code, paras. 30-31; FCA Listing Rules, 9.8.6(3).

78 FRC Financial Reporting Lab (2017a), p 21.

79 Hansard (2006), cols. 188-189 per Lord Sainsbury (Government spokesperson).
} 
for the dividend context. On the other hand, it might also be said that experience since the enactment of the Companies Act 2006 does not suggest that retention of a highly-prescriptive legal capital style approach to the regulation of dividends is effective to curb excessive value extraction. Whatever way it is examined, the position with respect to dividends looks deeply unsatisfactory. The following section goes deeper into the issues and possible options for reform.

\section{Distributions from Profits: Dividend Payments}

As with other legal capital rules, the EU regime in the Second Company Law Directive applies only to public companies. Nevertheless the opportunity was not taken to simplify the position for private companies in the Companies Act 2006 by allowing them to pay dividends on the basis of a directors' solvency statement. Instead for both public and private companies the law remained that dividends could only be paid out of accumulated net realised profits as well as an additional balance sheet test for public companies only, with the amount available for distribution being determined by reference to the reserves shown in the company's accounts. This was in spite of powerful arguments for change that centred both on technical considerations relating to developments in accounting standards that, it was argued, had made published accounts more useful for capital market investors but less suitable for the determination of distributable reserves and also on more general points about the outdated conceptual notions that underpinned the legal capital doctrine and the superiority of modern approaches that in focusing on solvency were felt to be better aligned with creditors' real concerns. Some parliamentarians did try to introduce a solvency-based regime for dividends by private companies into the Companies Bill (later 2006 Act) as it passed through Parliament, arguing that the existing position had fallen into 'disrepute' and was in need of 'urgent legal attention'. ${ }^{80}$ Yet amidst concern about the risks associated with a solvency-based approach, in particular that it might result in insufficient provision for long-term liabilities such as pensions, the more conservative position prevailed. ${ }^{81}$

With the benefit of hindsight we can see that faith in the intricacies of the legal capital doctrine as a bulwark against the extraction of value to the detriment of longterm liabilities such as pensions was misplaced. The failure of BHS in 2016 has come to epitomize the problem. ${ }^{82}$ BHS, a fixture on the UK high street since 1928 , was bought by Sir Philip Green in 2000. At the time of the acquisition there was a combined surplus of $£ 43$ million in the company pension schemes. By 2006 the pension schemes were in deficit. This reverse coincided with a period when large dividends, funded by loans, were paid out to the Green family. When BHS finally went into administration in 2016 the deficit in its employee pension schemes had grown

\footnotetext{
${ }^{80}$ Hansard (2006), cols. 186-187 per Baroness Goudie (and echoed by others).

81 Hansard (2006), cols. 188-189 per Lord Sainsbury.

82 This paragraph draws on House of Commons Work and Pensions and Business, Innovation and Skills Committees (2016).
} 
to more than $£ 200$ million. Public disquiet about disparity between dividend growth and pension scheme shortfalls was further deepened by the collapse of Carillion in $2017 .{ }^{83}$ In this case, the dividend increased in each of the 16 years since the formation of the company at the same time as the deficit on the pension schemes grew to an estimated $£ 800$ million. ${ }^{84}$ The parliamentary inquiry into Carillion noted that the policy of increasing the dividend year-on-year had been maintained notwithstanding that the cash-flow was not sufficient to cover the dividend and was fuelled by increased borrowing. ${ }^{85}$ Although many companies treat lack of available cash as a constraint on dividends, it is technically possible for a company to be compliant with the legal requirements on dividends yet have to borrow actually to pay the dividend because distributable reserves are not measured by reference to cash resources. Nevertheless questions have been asked as to whether Carillion's directors or auditors breached any of their legal duties in signing off on these dividends. ${ }^{86}$

Reference to BHS and Carillion is not to imply a direct causal link between dividends and pension scheme deficits since it is a multiplicity of factors that has made defined benefit schemes unaffordable. Nor is it meant to suggest that high-profile collapses inevitably indicate a systemic problem with dividends as opposed to (just) the possibility of questionable practices in individual cases. The point here is simply that the existing framework cannot credibly justify its existence by reference to the part it plays in restraining excessive dividends.

It might, of course, be argued that situations such as BHS and Carillion might have been even worse but for the layer of prudence imposed by the requirement to pay dividends only out of net realised profits and (for plcs) net asset surplus, as determined by reference to relevant accounts but the argument carries little weight. If we look back to the pre-2006 Act debate, there was real concern then that compliance with changing accounting requirements with respect to pension scheme liabilities would significantly impair dividend-paying capacity under the existing legal framework. ${ }^{87}$ Yet in 2017 alone, companies in the FTSE350 index paid $£ 8.3$ billion in aggregate pension deficit contributions compared to dividend payouts of $£ 66$ billion. ${ }^{88}$ To understand fully why fear of dividend blocks has been replaced by the reverse concern that the existing system is too generous involves an analysis of the complexities of pension scheme accounting that is beyond scope. But at a basic level it appears that a key part of the problem is that while pension deficits do have to be deducted from reserves available for distribution, the determination of a deficit under accounting standards is done on a less prudent basis than the actuarial calculations generally used for the purposes of determining pension deficit recovery

\footnotetext{
83 This passage draws on House of Commons Business, Energy and Industrial Strategy and Work and Pensions Committees (2018).

84 House of Commons Business, Energy and Industrial Strategy and Work and Pensions Committees (2018), para. 23.

85 House of Commons Business, Energy and Industrial Strategy and Work and Pensions Committees (2018), paras. 16-21.

86 Landell-Mills (2018).

87 Rickford (2004).

${ }^{88}$ Cumbo (2018).
} 
contributions. ${ }^{89}$ Of course directors should still consider any larger sum they are actually required to pay into their pension scheme in exercising their judgment on how much to pay out in dividends but the difference in the approaches means that they may have a quite a substantial cushion to play with before hitting the hard limit of the amount legally available for distribution. ${ }^{90}$

Added to this, we can also see that champions of reform a decade ago were right to predict that the interaction of complex legal and accounting requirements would make this area a minefield that companies and their advisers would find it increasingly difficult to navigate. The notion that distributable profits and accounting profits are conceptually different (so that if they happen to land in the same place that is just coincidental) is not new but the divergence has increased over the years, and especially so with the move to IFRS for financial reporting by listed companies and the modernisation of the Generally Accepted Accounting Practice in the UK (UK GAAP) with respect to fair value accounting because these trends have increased the likelihood of accounting profits including amounts that would not be regarded as 'realised' for distribution purposes. As a proxy for the intensification of the resulting complexities we can look at the expansion of the guidance published by accounting profession that is intended to help companies and their advisers identify, interpret and apply the relevant principles to differentiate between profits and distributable profits. When the profession first started to issue this supplementary guidance back in 1982 it was just a few pages in length ${ }^{91}$ but the modern equivalent now runs to over 170 pages. $^{92}$ Even prominent FTSE-listed companies have been tripped up by the complexities and found themselves in the position of having made illegal dividend payments as a result of 'technical infringements'. 93

Transparency (or the lack of it) around dividend policy has become an increasingly contentious issue. The determination of distributable reserves is linked to accounts in that the reference point for profits, losses, assets, liabilities, provisions, share capital and reserves is the paying company's 'relevant accounts' (usually its last annual accounts). ${ }^{94}$ However, there is no explicit provision in the Companies Act 2006 that requires companies specifically to distinguish in their accounts between realised and unrealised profits or between distributable and non-distributable profits. Leading barristers have given conflicting opinions on whether accounts give a true and fair view if they do not enable a determination of the profits available for distribution from the information in the accounts. ${ }^{95}$ The position maintained by (among others) the accounting profession and its current regulator, the

\footnotetext{
89 Peters (2016).

90 But in the past few years (partly related to Brexit) the threat of dividend cuts related to pension deficits has re-emerged.

91 Johnson and Patient (1985), Appendix VIII (reproducing ICAEW, TR481 and TR482).

92 ICAEW (2002).

93 The list of companies at fault includes Wm Morrison Supermarkets, Ladbrokes, Al Noor Hospitals, Foxtons, STV (Scottish TV), Betfair, and Next.

94 Companies Act 2006, s. 836.

95 Ramage (2017) (providing links to the Opinions of Martin Moore QC (for the FRC) and of George Bompas QC.
} 
Financial Reporting Council (FRC), is that financial statements need not include a specific statement on the level of available distributable reserves but this has been challenged by the Local Authorities Pension Fund Forum (LAPFF) and some other investors as a wrong interpretation of the law. ${ }^{96}$ A further problem from a transparency perspective is that within corporate groups it is the accounts of the parent company that pays the dividend to end shareholders that constitute the reference point yet the parent's individual profit and loss (income) statement may be omitted from the published accounts. ${ }^{97}$ The majority of UK listed companies take advantage of this exemption. ${ }^{98}$

A war of words between investors and the accounting establishment on (for nonspecialists) seemingly abstruse disclosure requirements is a bad sign as to how well the existing framework is functioning in practice. Normatively there is more agreement between the various camps on the need to improve disclosure around dividend policies and dividend resources both to attract investment and to enable investors to act as responsible stewards. It is evident from work led by the FRC's Financial Reporting Lab that investors want more information to help them understand the constraints associated with dividend policies. More assurance about the availability of distributable reserves (although not necessarily a precise figure) is part of the information that investors are seeking but they also want to be better informed about other constraints such as the availability of cash, gearing levels, debt covenants and regulatory capital requirements. ${ }^{99}$ Corporate reporting practice is gradually evolving to meet this demand. The most noticeable change reported thus far has been the inclusion in financial statements of reference to distributable profits or distributable reserves with 58\% of the FTSE 100 making some level of disclosure (up from $40 \%$ in 2015), and $48 \%$ disclosing the specific level of distributable profits/reserves of the holding company, the elements of distributable profits/reserves which are not distributable, or reference to distributable reserves as sufficient or significant. ${ }^{100}$ There is a possibility of this emerging practice being underpinned by legal obligation in due course; government has consulted on the sufficiency of transparency and accountability to shareholders and others about decisions about dividend payments. ${ }^{101}$

However, this paper argues for consideration of more radical change that could make disclosure relating to the level of distributable reserves a complete non-issue by ceasing to rely on distributable reserves as a binding constraint on dividendpaying capacity and transitioning to an alternative, liquidity/solvency-based regime. As discussed earlier, there was considerable support for such a transition in the

\footnotetext{
96 In 2016 the LAPFF wrote to FTSE350 companies urging them to disregard the FRC's position on dividend payments.

97 Companies Act 2006, s. 408.

98 FRC Financial Reporting Lab (2015), p 21.

99 FRC Financial Reporting Lab (2015), p 10.

100 FRC Financial Reporting Lab (2017b).

101 In the short term the government will wait to see whether best practice evolves to address concerns about the transparency of capital allocation decisions but says it is prepared to legislate if needed: Department for Business, Energy and Industrial Strategy (2018c), paras. 1.46-1.55.
} 
mid-2000s. ${ }^{102}$ The world is different today and reluctance to tamper with complex technical requirements that may not do much good yet at least provide an outer limit on what can be distributed can easily be anticipated. Nevertheless, by taking the long view it is possible to find several substantial reasons to keep the discussion alive and therefore to welcome the government's willingness to consider afresh the case for comprehensive reform. ${ }^{103}$

The level of undistributable/distributable reserves within a company reflects historic decisions on share issuance and capital structure as well as recent trading performance and, as such, at any given moment in time it may be too restrictive relative to performance, prospects and cash reserves to support otherwise entirely reasonable judgements by management that surplus value should be returned to shareholders because it cannot be put to productive use, or too generous relative to the other demands on the company's resources. Moreover, whilst the determination of available distributable reserves is (just) a legal outer limit on the amount that can legally be distributed and does not relieve directors of their responsibility to decide on the dividend it would be prudent to pay taking account of other commitments such as pension deficit contributions and their general duties, the nuances may not always be fully appreciated, resulting in directors finding it difficult to understand and discharge their responsibilities correctly. The stress on the need for distributable reserves may distract attention from more economically significant issues about liquidity and longer term solvency, or appear to suggest that these are merely secondary considerations. The availability of distributable reserves may thus provide false reassurance.

Technical problems abound: for example, dividend 'blocks' within corporate groups whereby for complex technical reasons reserves cannot be moved up to the level of dividend-paying company (usually the parent company) to support the level of dividend that would be consistent with the performance of the group as a whole; or the very fact that it is the accounts of the parent company rather than the consolidated group accounts that are the reference point for the determination of distributable reserves. Where confusion results in technical infringements, the recent trend has been to forgive the irregularity (often by rather complicated (and costly) procedures) ${ }^{104}$ rather than to pursue the responsible directors or to seek to recover the wrongly paid dividends; in this respect, the protection offered by the legal framework does not appear to be much valued in practice.

The core technical problem is the divergence between accounting profits and distributable profits, and, as discussed earlier, much of the complexity, including the

\footnotetext{
102 KPMG (2006), p 128 noting a 'strong climate of opinion' in the UK in favour of a fundamental reappraisal.

103 Department for Business, Energy and Industrial Strategy (2018c), para. 1.47.

104 Involving Deeds of Release approved by the company in general meeting that release the company's claims against the shareholders who received the dividend and the directors who authorised it. In the case of a listed company, approval of the Directors' Deed of Release as a related party transaction will also be required. For an example of a Circular to Shareholders and Notice of General Meeting: https:// www.nextplc.co.uk/ /media/Files/N/Next-PLC-V2/documents/company-meetings/general-meeting-circu lar-Jan2016.pdf.
} 
need for voluminous guidance from the accounting profession, flows from that This divergence was accentuated by the transition to IFRS but in recent years IFRS have come under attack for being insufficiently prudent, especially with regard to the recognition of profits. ${ }^{105}$ A major driver of this has been dissatisfaction with the role of IFRS in the financial crisis. This discontent led to an overhaul of some standards (in particular the adoption of IFRS 9 Financial Instruments, described as combining 'fair value accounting with the more cautious approach of predecessor standards' $)$ 106 and was part of the background to a revamp of the overall Conceptual Framework for IFRS reporting. The most recent version of the Conceptual Framework includes reference to 'prudence' although it does not go as far as some critics had called for because it does not incorporate an asymmetric form of prudence which would involve applying a lower threshold for the recognition of liabilities and losses than for assets and gains. ${ }^{107}$ The Conceptual Framework also gives limited ground to critics in another important and relevant respect by clarifying that the objective of financial statements-to provide financial information that is useful to users in making decisions relating to providing resources to the entity-includes information that is helpful to users in assessing management's stewardship of the entity's economic resources. ${ }^{108}$ However, calls for more radical reform continue to be made. ${ }^{109}$

The paper cannot go deeper into the debate around IFRS and does not need to. The relevant point is that 'fixing' the accounting standards is part of the picture, but so too is 'fixing' the legal requirements and the proposition here is that an exercise in fixing the legal side should include re-examining whether to move away from the legal capital doctrine to an approach that has liquidity/solvency at its centre. (Though as an incidental point with regard to IFRS, it is just worth noting that whilst Brexit would present the possibility in theory of breaking away entirely from IFRS, that does not seem to be a realistic option).

\section{Outlining the Reform Agenda and Concluding}

There is a clear need for intervention to curb the societal harm that can flow from excessive dividends and other forms of value extraction from companies. However, whilst company law and corporate governance have acquired a regulatory dimension that goes beyond the older conception of their core purpose as being to address internal agency problems between owners and managers, the heavy lifting with regard to societal concerns is best done by public interest focused regulatory regimes. There are already in existence various regulatory intervention powers to restrict the payment of dividends in certain circumstances, including, for example, the powers of

\footnotetext{
105 Prudence being defined as 'the exercise of caution when making judgements under conditions of uncertainty': International Accounting Standards Board (2018), para. 2.16.

106 FT Editorial (2018).

107 International Accounting Standards Board (2018), para. 2.17.

108 International Accounting Standards Board (2018), paras. 1.2-1.4.

109 E.g., FT Editorial (2018).
} 
bank supervisors to restrict or prohibit dividends and the restrictions that are triggered when a bank fails to meet capital adequacy requirements are examples of this type of intervention. ${ }^{110}$ Another example, which is of direct relevance to the issues discussed in this paper, is the intervention power of the Pensions Regulator under section 231 of the Pensions Act 2004. This power was recently used against Southern Water Services Ltd in circumstances where the Regulator considered that the company's defined benefit pension scheme was carrying unnecessary risk due to a recovery plan that extended over a long period during which time the company was planning to pay dividends to shareholders. The outcome of the intervention was that the company agreed to pay significantly higher deficit recovery contributions under a shorter recovery plan and also to accelerate the recovery contributions if dividends outside of the group to shareholders exceeded an agreed threshold. Other such targeted powers could be introduced and/or the use of existing ones could be stepped up. Bearing in mind the importance of dividend income for pension funds and others, the adoption and the use of such public interest powers must, of course, be carefully calibrated so as not to undermine investors' reasonable expectations regarding investment returns.

With company law relieved of the obligation singe-handedly to address societal concerns, attention could then turn to reviewing the dividend framework as part of a much broader agenda to keep company law up to date and focused on long term sustainable corporate success. It is apparent from the experience of other countries that a liquidity/solvency-based approach could take a variety of forms. The existing solvency statement procedure for reduction of capital is an obvious starting point but there are other models for what a modern approach could look like. Much work was done on identifying different models already in operation around the world prior to the Companies Act 2006 and that learning is still available. ${ }^{111}$ Comparative reference could also be made to states and countries that have gone through their own reform exercise in the intervening years. One example is Australia where the law was changed in 2010 to permit dividends to be paid from profits or other reserves provided the company remained solvent. ${ }^{112}$ The conditions for a lawful dividend are that the company's assets exceed its liabilities before the dividend is declared and the excess is sufficient for the payment of the dividend (a 'balance sheet' test); the dividend is fair and reasonable to the shareholders as a whole; and the payment of the dividend does not materially prejudice the company's ability to pay its creditors. There has been some teething trouble with this reform but lessons from that type of experience can be just as valuable as those drawn from alternative frameworks that

\footnotetext{
110 These powers and restrictions are derived from Directive 2013/36/EU of the European Parliament and of the Council of 26 June 2013 on access to the activity of credit institutions and the prudential supervision of credit institutions and investment firms [2013] OJ L176/338. It is assumed that the UK will continue to apply this prudential framework, which is based on and gives effect to the Basel standards agreed at international level.

111 Two detailed sources are Rickford (2004); KPMG (2006).

112 Australian Corporations Act 2001, s. 254T(1).
} 
are working well. ${ }^{113}$ Singapore also considered reform during this period but was not persuaded to adopt a liquidity/solvency-based approach for dividends because current rules were 'well known and had the advantage of being simple and straightforward'. ${ }^{114}$ Important differences between Singapore and UK law is that under Singaporean law dividends are payable out of 'profits' without the additional gloss that profits must be 'realised' and prior accumulated losses need not be cleared before payment of dividends is allowed. Aligning Singaporean law more closely to UK law did not appeal 'because it would complicate the issue'. ${ }^{115}$ Potentially fruitful reference could also be made to developments in US corporations law, where pockets of older thinking persisted notwithstanding an overall trend in State laws away from legal capital, for example the background to and experience of simplifying amendments to the California Corporations Code in 2011 that gave boards of directors of corporations more latitude when determining amounts available for distribution, including permitting them to consider fair values rather than historical carrying costs and to base their determination on valuations derived from any method that was reasonable in the circumstances.

Should the option of radical reform fail to gain traction in the UK, a 'half way house' would be to abolish the 'realisation' requirement and link dividend-paying capacity simply to accounting profits, to this extent mirroring the Singapore position. That would at least remove the need for extensive guidance on the realisation concept. Dispensing with one of the layers of complexity would go some way towards making it harder for directors to hide between technicalities in discharging their responsibilities and could also facilitate stronger accountability. This could even be packaged as a Brexit related reform although technically realisation is a domestic requirement not imposed by EU law.

Mention of Brexit takes the discussion in this paper full circle. Taking Centros as its point of departure, this paper has argued for the revival of interest in an old idea-reform of the legal capital (maintenance of capital) doctrine. Brexit is relevant to the extent that it could provide the UK with the opportunity to make more radical changes than are open to it as a Member State. But to reform legal capital just because Brexit may make it possible to do so would have little merit. This paper has drawn upon experience since Centros and, more particularly, since the enactment of the UK Companies Act 2006 to put forward some rather more substantial arguments in favour of revisiting legal capital. Three points stand out. First, recent corporate collapses have shown that any lingering belief in the legal capital doctrine as an effective bulwark against short termist corporate behaviour should finally be retired. Second, events have tended to confirm the pessimistic predictions that were around at the time of the Companies Act 2006 with regard to increasing complexity

\footnotetext{
113 There is uncertainty whether the distinction between capital and profit continues. Case law strongly suggests that dividends can be paid from capital as well as profits: Grant-Taylor v. Babcock \& Brown Ltd (In Liquidation) [2016] FCAFC 60 at paras. 37-39 but technically these remarks were not strictly necessary to the Court's decision.

114 Ministry of Finance Steering Committee for Review of the Companies Act (2011), para. 117.

115 Ministry of Finance Steering Committee for Review of the Companies Act (2011), para. 119.
} 
associated with applying the legal rules on distributions in the context of modern financial reporting requirements. Third, the practical operation of reforms introduced by the Companies Act 2006 have led to a more mature understanding, including binding legal authority, on how a solvency statement-based approach works to protect creditors' interests. There is also an increasingly substantial body of comparative learning on how to move away from legal capital to draw upon, including from countries and states that have recently reformed their laws.

This paper has located the need for reform of legal capital within the broader agenda for a system of effective corporate governance and regulation that supports economically worthwhile and sustainable business activity. Modernising the baseline conditions governing capital structure and value retention/extraction is best thought of as a complementary step to be taken alongside deep reflection on how best to incentivise corporate management to use their discretionary powers in ways that are sustainable, compatible with the interests of all corporate stakeholders and not harmful to society as a whole.

Acknowledgements I am grateful to Gareth Sykes of Herbert Smith Freehills and delegates at the ECGI conference 'Centros and European Company Law: Twenty Years of Living Dangerously', 15 March 2019, University of Oxford, for comments and suggestions. Remaining errors are my own.

Open Access This article is distributed under the terms of the Creative Commons Attribution 4.0 International License (http://creativecommons.org/licenses/by/4.0/), which permits unrestricted use, distribution, and reproduction in any medium, provided you give appropriate credit to the original author(s) and the source, provide a link to the Creative Commons license, and indicate if changes were made.

\section{References}

Armour J et al (2017) Brexit and corporate citizenship. EBOR 18:225-249

Böckli P et al (2017) The consequences of Brexit for companies and company law. University of Cambridge Faculty of Law Research Paper No. 22/2017

Company Law Review Steering Group (1999a) Modern company law for a competitive economy: the strategic framework. URN 99/654

Company Law Review Steering Group (1999b) Modern company law for a competitive economy: company formation and capital maintenance. URN 99/1144

Company Law Review Steering Group (2000) Modern company law for a competitive economy: capital maintenance: other issues. https://webarchive.nationalarchives.gov.uk/20121101192107. http:// www.bis.gov.uk/files/file23244.pdf. Accessed 3 June 2019

Cumbo J (2018) UK companies pay far more in dividends than pension contributions. Financial Times, 2 August 2018

Department for Business, Energy and Industrial Strategy (2016) Corporate governance reform: green paper. November 2016. https://assets.publishing.service.gov.uk/government/uploads/system/uploa ds/attachment_data/file/584013/corporate-governance-reform-green-paper.pdf. Accessed 3 June 2019

Department for Business, Energy and Industrial Strategy (2017) Corporate governance reform: the Government response to the green paper consultation. August 2017. https://assets.publishing.servi ce.gov.uk/government/uploads/system/uploads/attachment_data/file/640470/corporate-governance -reform-government-response.pdf. Accessed 24 July 2019

Department for Business, Energy and Industrial Strategy (2018a) Government to research whether companies buy back their own shares to inflate executive pay. Press release, 28 January 2018. https:// 
www.gov.uk/government/news/government-to-research-whether-companies-buy-back-their-ownshares-to-inflate-executive-pay. Accessed 27 July 2019

Department for Business, Energy and Industrial Strategy (2018b) Insolvency and corporate governance consultation. 20 March 2018. https://assets.publishing.service.gov.uk/government/uploads/system/ uploads/attachment_data/file/691857/Condoc_-_Insolvency_and_Corporate_Governance_FINAL _.pdf. Accessed 27 July 2019

Department for Business, Energy \& Industrial Strategy (2018c) Insolvency and corporate governance: government response. 26 August 2018. https://assets.publishing.service.gov.uk/government/uploa ds/system/uploads/attachment_data/file/736207/ICG_-_Government_response_doc_-_24_Aug_ clean_version_with_Minister_s_photo_and_signature_AC_final.pdf. Accessed 3 June 2019

Department for Business, Energy \& Industrial Strategy (2019a) Independent review of the Financial Reporting Council: initial consultation on recommendations. March 2019. https://assets.publishing .service.gov.uk/government/uploads/system/uploads/attachment_data/file/784988/independent-revie w-financial-reporting-council-initial-consultation-recommendations.pdf. Accessed 27 July 2019

Department for Business, Energy \& Industrial Strategy (2019b) Share repurchases, executive pay and investment. July 2019. https://assets.publishing.service.gov.uk/government/uploads/system/uploa ds/attachment_data/file/817978/share-repurchases-executive-pay-investment.pdf. Accessed 27 July 2019

Department for Work and Pensions (2018) Protecting defined benefit pension schemes. Cm 9591, March 2018

Department of Trade and Industry (2005) Company law reform. Cm 6456

Department of Trade and Industry (2007) Implementation of the Companies Act 2006: a consultative document. URN 07/666

Ferran E, Ho LC (2013) Principles of corporate finance law, 2nd edn. OUP, Oxford

FRC Financial Reporting Lab (2015) Disclosure of dividends-policy and practice. November 2015. https://www.frc.org.uk/getattachment/96ac6006-7a5a-4c69-8c30-010191139ec4/Lab-Project-Repor t-Disclosure-of-dividends-policy-and-practice.pdf. Accessed 3 June 2019

FRC Financial Reporting Lab (2017a) Risk and viability reporting. November 2017. https://www.frc. org.uk/getattachment/76e21dee-2be2-415f-b326-932e8a3fc1e6/Risk-and-Viability-Reporting.pdf. Accessed 3 June 2019

FRC Financial Reporting Lab (2017b) Disclosure of dividends-policy and practice: Lab implementation study. October 2017. https://www.frc.org.uk/getattachment/3a7972af-35ae-4354-8136-0b395f5bbb ba/Dividends-implementation-study-Lab.pdf. Accessed 3 June 2019

FRC (2018a) Big four audit quality review results decline. Press release, 18 June 2018. https://www.frc. org.uk/news/june-2018/big-four-audit-quality-review-results-decline. Accessed 3 June 2019

FRC (2018b) The audit of defined pension obligations: findings from 1017/18 audit quality reviews. July 2018. https://www.frc.org.uk/getattachment/4fbf1bb2-930b-4032-a5be-b93aa84f06f0/Audit-ofdefined-benefit-pension-obligations_v4.pdf. Accessed 3 June 2019

FT Editorial (2018) Reform accounting rules to restore trust in audit. Financial Times, 2 August 2018

Gelter M, Reif A (2017) What is dead may never die: the UK's influence on EU company law. Fordham Int Law J 40:1413-1442

Grier N (2014) Enlightened shareholder value: did directors deliver? Juridical Rev 2:95-111

Haldane AG (2015) Who owns a company?. Speech delivered at University of Edinburgh Corporate Finance Conference, 22 May 2015. https://www.bankofengland.co.uk/-/media/boe/files/speec h/2015/who-owns-a-company.pdf. Accessed 27 July 2019

Hansard (2006) House of lords, vol 682, 16 May 2006

House of Commons Business, Energy and Industrial Strategy Committee (2017) Corporate governance. HC702, 5 April 2017

House of Commons Business, Energy and Industrial Strategy and Work and Pensions Committees (2018) Carillion. HC 769, 16 May 2018

House of Commons Work and Pensions and Business, Innovation and Skills Committees (2016) BHS, first report. HC 54, 20 July 2016

Hudson A (2016) BHS and the reform of company law. Co Lawyer 37:364-371

Hudson A (2018) Understanding company law, 2nd edn. Routledge, New York

ICAEW (2002) Guidance on realised and distributable profits under the Companies Act 2006. TECH $02 / 17 \mathrm{BL}$ 
ICAEW Financial Reporting Faculty (2017) Brexit: implications for financial reporting. https://www. icaew.com/-/media/corporate/files/technical/financial-reporting/information-for-better-markets/brexi t-implications-for-financial-reporting.ashx. Accessed 27 July 2019

Infogroup/ORC International (2010) Evaluation of the Companies Act 2006, volume one: Report to the Department for Business, Innovation and Skills. August 2010. https://assets.publishing.service.gov. uk/government/uploads/system/uploads/attachment_data/file/31655/10-1360-evaluation-companiesact-2006-volume-1.pdf. Accessed 27 July 2019

International Accounting Standards Board (2018) Conceptual framework for financial reporting. March 2018. https://www.ifrs.org/issued-standards/list-of-standards/conceptual-framework/. Accessed 27 July 2019

Johnson B, Patient M (1985) Accounting provisions of the Companies Act 1985. Farringdon Publishing, London

Keay A (2012) The enlightened shareholder value principle and corporate governance. Routledge, Oxford

Kingman J (2018) Independent review of the Financial Reporting Council. December 2018. https://asset s.publishing.service.gov.uk/government/uploads/system/uploads/attachment_data/file/767387/frcindependent-review-final-report.pdf. Accessed 27 July 2019

KPMG (2006) Feasibility study on an alternative to the capital maintenance regime established by the Second Company Law Directive 77/91/EEC of 13 December 1976 and an examination of the impact on profit distribution of the new EU-accounting regime

Landell-Mills $\mathrm{N}$ et al (2018) Carillion's woes may point to a much deeper problem. Financial Times, 23 January 2018

Lynch E (2012) Section 172: a ground-breaking reform of director's duties, or the emperor's new clothes? Co Lawyer 33:196-203

Ministry of Finance Steering Committee for Review of the Companies Act (2011) Report. June 2011. https:/www.mof.gov.sg/portals/0/data/cmsresource/public\%20consultation/2011/Review\%20of\%20 Companies\%20Act\%20and\%20Foreign\%20Entities\%20Act/Annex\%20A\%20SC\%20Report\%20 Complete\%202.pdf. Accessed 27 July 2019

Moore MT (2017) Shareholder primacy, labour and the historic ambivalence of UK Company Law. In: Wells H (ed) Research handbook on the history of corporate law. Edward Elgar, Cheltenham, pp $142-169$

Peters B (2016) Dividends, reserves and pension deficits. 16 June 2016. http://pwc.blogs.com/pensi ons/2016/06/dividends-reserves-and-pension-deficits-.html. Accessed 27 July 2019

Plender J (2018) Executive pay rows show that governance matters. Financial Times, 25 July 2018

Ramage R (2017) True and fair view_opinions. http://www.law-office.co.uk/true\&fair_opinions.htm. Accessed 27 July 2019

Rickford J (2004) Reforming capital. Eur Bus Law Rev 15:919-1027

Safari N, Gelter M (2019) British home stores collapse: evidence for the need of employees' derivative claim right. J Corp Law Stud 19:43-68

Sakinç ME (2017) Share repurchases in Europe: a value extraction analysis. The Academic-Industry Research Network Working Paper 16/2017

Schillig M (2016) Corporate law after Brexit. King's Law J 27:431-441

The Pensions Regulator (2018) Annual funding statement. https://www.tpr.gov.uk/-/media/thepension sregulator/files/import/pdf/db-annual-funding-statement-2018.ashx. Accessed 27 July 2019

Tooze A (2018) Crashed: how a decade of financial crises changed the world. Viking, New York

Walker-Arnott E (2017) A true and fair view: the difficulties for company directors and the case for reform. J Bus Law 499-527

Weightmans (2017) The solvency statement: reducing share capital. October 2017. https://www.weigh tmans.com/insights/the-solvency-statement/. Accessed 27 July 2019

Williams R (2012) Enlightened shareholder value in UK Company Law. UNSW Law J 35:360-377

Publisher's Note Springer Nature remains neutral with regard to jurisdictional claims in published maps and institutional affiliations. 